\title{
Effects of ticlopidine on pharmacokinetics of losartan and its main metabolite EXP-3174 in rats
}

\author{
Si-hyung $\mathrm{YANG}^{1}$, Young-ah $\mathrm{CHO}^{2}$, Jun-shik $\mathrm{CHOI}^{3, *}$ \\ ${ }^{1}$ College of Medicine, Dankook University, Cheonan 330-714, Korea; ${ }^{2}$ College of Medicine, Research Institute of Life Science, Gyeong- \\ sang National University, Jinju 660-701, Korea; ${ }^{3}$ College of Pharmacy, Chosun University, Gwangju 501-759, Korea
}

\begin{abstract}
Aim: Losartan and antiplatelet agent ticlopidine can be prescribed concomitantly for prevention or therapy of cardiovascular diseases. Hence, the effects of ticlopidine on the pharmacokinetics of losartan and its active metabolite EXP-3174 were evaluated in rats. Methods: Ticlopidine ( 4 or $10 \mathrm{mg} / \mathrm{kg}$ po) was administered $30 \mathrm{~min}$ before administration of losartan (9 mg/kg po or $3 \mathrm{mg} / \mathrm{kg}$ iv). The activity of human CYP2C9 and 3A4 were measured using the CYP inhibition assay kit. The activity of P-gp was evaluated using rhodamine-123 retention assay in MCF-7/ADR cells.

Results: Ticlopidine $(10 \mathrm{mg} / \mathrm{kg}$ ) significantly increased the areas under the plasma concentration-time curves (AUCs) and peak plasma concentration $\left(C_{\max }\right)$ of oral losartan $(9 \mathrm{mg} / \mathrm{kg})$, as well as the AUCs of the active metabolite EXP-3174. Ticlopidine (10 mg/kg) did not significantly change the pharmacokinetics of intravenous losartan (3 mg/kg). Ticlopidine inhibited CYP2C9 and $3 A 4$ with IC ${ }_{50}$ values of 26.0 and $32.3 \mu \mathrm{mol} / \mathrm{L}$, respectively. The relative cellular uptake of rhodamine-123 was unchanged.

Conclusion: The significant increase in the AUC of losartan $(9 \mathrm{mg} / \mathrm{kg})$ by ticlopidine $(10 \mathrm{mg} / \mathrm{kg})$ could be attributed to the inhibition of CYP2C9- and 3A4-mediated losartan metabolism in small intestine and/or in liver. The inhibition of P-gp in small intestine and reduction of renal elimination of losartan by ticlopidine are unlikely to be causal factors.
\end{abstract}

Keywords: pharmacokinetics; Iosartan; EXP-3174; ticlopidine; CYP2C subfamily; CYP3A; P-glycoprotein

Acta Pharmacologica Sinica (2011) 32: 967-972; doi: 10.1038/aps.2011.32; published online 13 Jun 2011

\section{Introduction}

Losartan (DuP 753, MK-954), an angiotensin II receptor antagonist, has a low side-effect profile and is approved for the treatment of hypertension, alone or in combination with other agents $^{[1]}$. After oral administration, losartan is almost completely absorbed and extensively metabolized to a carboxylic acid derivative, EXP-3174, mainly by cytochrome P450 (CYP) 2C9 and 3A4 $4^{[2]}$. EXP-3174 is a major active metabolite in both rats and humans and is a more potent inhibitor of angiotensin II receptor than losartan, with high-affinity receptor specificity ${ }^{[3]}$. Losartan has also been reported to be a substrate of P-glycoprotein $(\mathrm{P}-\mathrm{gp})^{[4]}$. Considering that losartan is a substrate of both CYP enzymes and P-gp, the modulation of CYP and P-gp activities may cause significant changes in the pharmacokinetic profiles of losartan and its active metabolite, EXP3174.

Ticlopidine, a potent antiplatelet agent induced by adenosine diphosphate, is used for the treatment of a variety of

\footnotetext{
* To whom correspondence should be addressed.

E-mail jsachoi@chosun.ac.kr

Received 2011-01-04 Accepted 2011-03-23
}

platelet-dependent disease states ${ }^{[5]}$. Several papers recommend ticlopidine as a valuable alternative when patients cannot tolerate aspirin ${ }^{[6,7]}$. It has been reported that ticlopidine causes significant inhibition of several drugs metabolized by the hepatic CYP enzyme system ${ }^{[8,9]}$.

Clinically, losartan and ticlopidine can be prescribed concomitantly for the prevention or therapy of cardiovascular diseases. However, the pharmacokinetic interaction between ticlopidine and losartan in vivo has not yet been reported. Therefore, the present study aimed to evaluate the effect of ticlopidine on the pharmacokinetics of losartan and its active metabolite, EXP-3174, in rats. The effects of ticlopidine on P-gp, CYP2C9, and 3A4 activities were also evaluated.

\section{Materials and methods Chemicals}

Losartan, EXP-3174, L-158.809 (internal standard), acetonitrile, methanol, and tert-butylmethylether were purchased from Merck Corporation (Darmstadt, Germany). Ticlopidine was purchased from Sigma-Aldrich Corporation (St Louis, MO, USA). All other chemicals were of reagent grade, and all solvents were of HPLC grade. 


\section{Rats}

The protocols for the animal studies were approved by the Animal Care Committee of Chosun University (Gwangju, Korea). Male Sprague-Dawley rats (7-8 weeks old, weighing 270-300 g) were purchased from Dae Han Laboratory Animal Research Company (Eumsung, Korea). The procedures used to maintain and handle the rats were similar to reported methods ${ }^{[10]}$.

\section{Oral and intravenous administrations of losartan and ticlopidine}

Losartan was orally or intravenously administrated, whereas ticlopidine was administrated orally. Oral losartan and ticlopidine were dissolved in distilled water $(5$ and $4 \mathrm{~mL}$, respectively). Intravenous losartan was dissolved in $0.9 \%$ $\mathrm{NaCl}$ solution $(4 \mathrm{~mL})$. The rats were randomly divided into six groups ( $n=6$ each): oral losartan $(9 \mathrm{mg} / \mathrm{kg})$ without and with oral ticlopidine (4 or $10 \mathrm{mg} / \mathrm{kg}$ ); intravenous losartan (3 $\mathrm{mg} / \mathrm{kg}$ ) without and with oral ticlopidine (4 or $10 \mathrm{mg} / \mathrm{kg}$ ). The rats were fasted for at least $24 \mathrm{~h}$ prior to the beginning of the experiments. Each animal was anaesthetized with light ether and the right femoral artery (for blood sampling) or vein (for iv administration of losartan) was cannulated with a polyethylene tube (SP45, ID $0.58 \mathrm{~mm}$, OD $0.96 \mathrm{~mm}$; Natsume Seisakusho, Tokyo, Japan). Ticlopidine was orally administered $30 \mathrm{~min}$ before oral administration of losartan. Oral losartan and ticlopidine were administered using a gastric gavage tube. A blood sample (approximately $0.5 \mathrm{~mL}$ ) was collected into a heparinized tube at 0 (control), 0.017 (end of the infusion), $0.1,0.25,0.5,1,2,4,8$, and $12 \mathrm{~h}$ after iv administration, and $0,0.1,0.25,0.5,1,2,4,6,8$, and $12 \mathrm{~h}$ after oral administration. Approximately $1 \mathrm{~mL}$ of whole blood collected from untreated rats was infused via the femoral artery at $0.25,1$, and $4 \mathrm{~h}$ to replace the blood loss due to blood sampling. Each blood sample was centrifuged at $16810 \times g$ for $5 \mathrm{~min}$, and $200 \mu \mathrm{L}$ of each plasma sample was stored at $-40{ }^{\circ} \mathrm{C}$ until HPLC analysis of losartan and EXP-3174 was performed ${ }^{[11]}$.

\section{HPLC assay}

Plasma concentrations of losartan were determined using an HPLC assay, which was modified from the reported method $^{[11]}$. Briefly, a $50 \mu \mathrm{L}$ aliquot of L-158.809 (internal standard, $5 \mu \mathrm{g} / \mathrm{mL}$ dissolved in methanol) and a $0.5 \mathrm{~mL}$ aliquot of acetonitrile were added to a $0.2 \mathrm{~mL}$ aliquot of the plasma sample in a $2.0 \mathrm{~mL}$ polypropylene microtube. The solution was then mixed for 5 min using a vortex-mixer (Vortex-Genie 2, Scientific Industries, Bohemia, NY, USA) and centrifuged for $10 \mathrm{~min}(16810 \times \mathrm{g})$. A $0.5 \mathrm{~mL}$ aliquot of the supernatant was transferred to a clean test tube and evaporated under a gentle stream of nitrogen gas at $35^{\circ} \mathrm{C}$. The residue was reconstituted in $150 \mu \mathrm{L}$ of the mobile phase and $70 \mu \mathrm{L}$ was injected directly onto a reversed-phase $\left(\mathrm{C}_{18}\right.$; Luna; $4.6 \mathrm{~mm}$ id $\times 250 \mathrm{~mm}$, particle size $5 \mu \mathrm{m}$, Phenomenex, Torrance, CA, USA) HPLC column. The HPLC system used in this study was comprised of a Waters 1515 isocratic HPLC Pump, a Waters 717 plus autosampler, a Waters 474 scanning fluorescence detector (Waters, Milford, MA, USA), and an HPLC column tempera- ture controller (ThermaSphere TS-430, Phenomenex, Torrance, CA, USA). The mobile phase, acetonitrile- $0.01 \mathrm{~mol} / \mathrm{L}$ phosphate buffer $(41: 59, v / v, \mathrm{pH} 2.5$, adjusted with phosphoric acid), was run at a flow rate of $0.8 \mathrm{~mL} / \mathrm{min}$ and the column eluent was monitored using an ultraviolet detector at $215 \mathrm{~nm}$. The retention times of L-158.809 (internal standard), losartan, and EXP-3174 were 6.27, 11.4, and $17.8 \mathrm{~min}$, respectively. The lower limit of quantification for both losartan and EXP-3174 in rat plasma was $5 \mathrm{ng} / \mathrm{mL}$. The coefficients of variation for losartan and EXP-3174 were below $13.9 \%$ and $15.9 \%$, respectively.

\section{CYP inhibition assay}

The inhibition assays for human CYP2C9 and 3A4 enzyme activities were performed in multiwell plates using the CYP inhibition assay kit (Gentest, Woburn, MA, USA) as previously described $^{[12]}$. Briefly, human CYP enzymes were obtained from baculovirus-infected insect cells. CYP substrates [150 $\mathrm{mmol} / \mathrm{L}$ 7-methoxy-4-trifluoromethyl coumarin (7-MFC) and $50 \mathrm{mmol} / \mathrm{L}$ 7-benzyloxy-4-(trifluoromethyl) coumarin (7-BFC) for CYP2C9 and 3A4, respectively] were incubated with or without test compounds in a reaction mix containing 1 pmol of P450 enzyme and the NADPH-generating system (1.3 $\mathrm{mmol} / \mathrm{L}$ NADP, $3.54 \mathrm{mmol} / \mathrm{L}$ glucose 6-phosphate, $0.4 \mathrm{U} / \mathrm{mL}$ glucose 6-phosphate dehydrogenase and $3.3 \mathrm{mmol} / \mathrm{L} \mathrm{MgCl}_{2}$ ) in potassium phosphate buffer ( $\mathrm{pH} 7.4)$. Reactions were terminated after $30 \mathrm{~min}$ by the addition of stop solution. Metabolite concentrations were measured with a spectrofluorometer (Molecular Device, Sunnyvale, CA, USA) set at an excitation wavelength of $409 \mathrm{~nm}$ and an emission wavelength of $530 \mathrm{~nm}$. Positive controls $(2 \mu \mathrm{mol} / \mathrm{L}$ sulfaphenazole and $1 \mu \mathrm{mol} / \mathrm{L}$ ketoconazole for CYP2C9 and 3A4, respectively) were run on the same plate and produced $99 \%$ inhibition. All experiments were performed in duplicate, and the results are expressed as percent inhibition.

\section{Rhodamine-123 retention assay}

MCF-7/ADR, a doxorubicin-resistant human breast cancer cell line, was used and seeded on 24-well plates at a density of $10^{5}$ cells. At $80 \%$ confluence, the cells were incubated in FBSfree DMEM for $18 \mathrm{~h}$. The culture medium was then changed to Hanks' balanced salt solution, and the cells were incubated at $37^{\circ} \mathrm{C}$ for $30 \mathrm{~min}$. After incubating the cells with $20 \mu \mathrm{mol} / \mathrm{L}$ rhodamine-123 in the presence of ticlopidine $(1,3,10$, and 30 $\mu \mathrm{mol} / \mathrm{L}$ ) for $90 \mathrm{~min}$, the medium was completely removed. The cells were then washed three times with ice-cold phosphate buffer ( $\mathrm{pH} 7.0$ ) and lysed in lysis buffer. Rhodamine-123 fluorescence was measured in the cell lysates using excitation and emission wavelengths of 480 and $540 \mathrm{~nm}$, respectively. Fluorescence values were normalized to the total protein content of each sample and presented as a ratio compared with control values. Verapamil $(100 \mu \mathrm{mol} / \mathrm{L})$ was used as a positive control.

\section{Pharmacokinetic analysis}

Standard methods ${ }^{[13]}$ were used to calculate the following 
pharmacokinetic parameters using non-compartmental analysis (WinNonlin software version 4.1; Pharsight Corporation, Mountain View, CA, USA): total area under the concentration-time curve (AUC) ${ }^{[14]}$, time-averaged total body clearance (CL), terminal half-life, first moment of AUC (AUMC), mean residence time (MRT), and apparent volume of distribution at steady state $\left(V_{\mathrm{ss}}\right)$. The extent of absolute oral bioavailability $(F)$ was estimated by $\mathrm{AUC}_{\text {oral }} / \mathrm{AUC}_{\text {iv }} \times$ Dose $_{\text {iv }} /$ Dose $_{\text {oral }} \times 100$. The peak concentration $\left(C_{\max }\right)$ and the time to reach peak concentration $\left(t_{\max }\right)$ of losartan and EXP-3174 were determined directly from the experimental data.

\section{Statistical analysis}

$P$-values $<0.05$ were deemed to be significant using the Social Package of Statistical Sciences (SPSS) posteriori analysis of variance (ANOVA) for the unpaired data and then individual differences among groups were determined using Duncan's multiple range test. All data are expressed as the mean \pm standard deviation (SD).

\section{Results}

\section{Inhibition of CYP2C9 and 3A4}

The inhibitory effects of ticlopidine on CYP2C9 and 3A4 activities are shown in Figure 1. Ticlopidine inhibited CYP2C9 and $3 \mathrm{~A} 4$ with $\mathrm{IC}_{50}$ values of 26.0 and $32.3 \mu \mathrm{mol} / \mathrm{L}$, respectively.
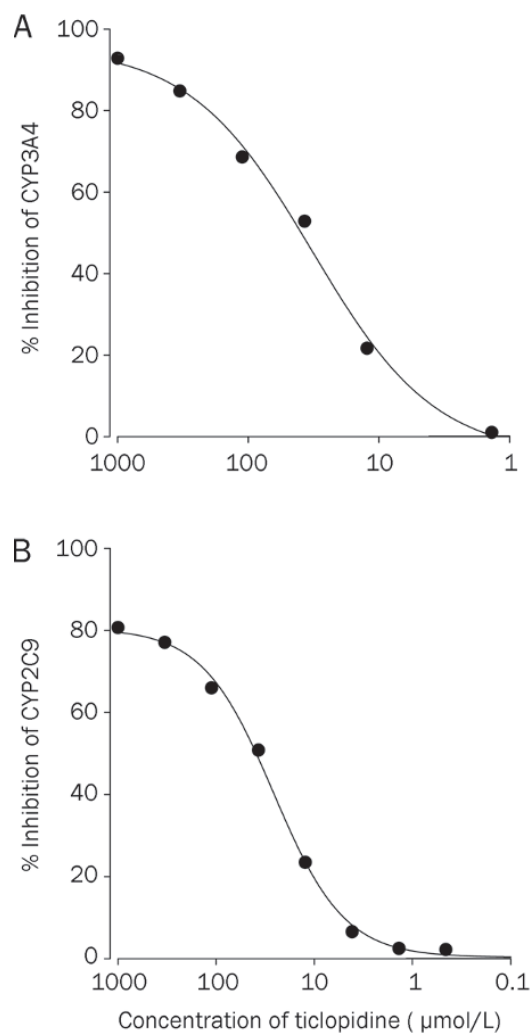

Figure 1. Inhibitory effects of ticlopidine on CYP3A4 (A) and 2C9 (B) activity. All experiments were performed in duplicate, and results were expressed as the percent inhibition.

\section{Rhodamine -123 retention assay}

The effects of ticlopidine on the cellular accumulation of rhodamine-123 in MCF-7 and MCF-7/ADR cells are shown in Figure 2. Accumulation of rhodamine-123 was reduced in MCF-7/ADR cells overexpressing P-gp compared to MCF-7 cells lacking P-gp. The relative cellular uptake of rhodamine-123 was comparable between the two conditions at the concentration range of $1-30 \mu \mathrm{mol} / \mathrm{L}$ ticlopidine.

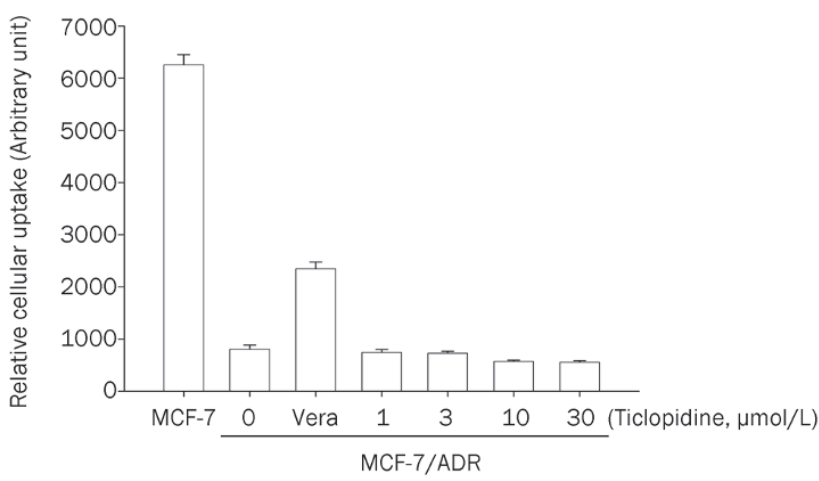

Figure 2. Effect of ticlopidine on the cellular accumulation of rhodamine-123 in MCF-7 and MCF-7/ADR cells. Mean \pm SD $(n=6)$.

Effect of ticlopidine on the pharmacokinetics of oral losartan

Rats were given oral administration of losartan $(9 \mathrm{mg} / \mathrm{kg})$ with and without oral administration of ticlopidine at doses of 4 and $10 \mathrm{mg} / \mathrm{kg}$. The mean arterial plasma concentrationtime profiles of losartan are shown in Figure 3. The relevant pharmacokinetic parameters of losartan are listed in Table 1. Absorption of losartan was rapid; losartan was detected in plasma at the first blood sampling time point (5 min) with a rapid $t_{\max }(1-2 \mathrm{~h})$ for all rats studied (Figure 3$)$. The AUC and

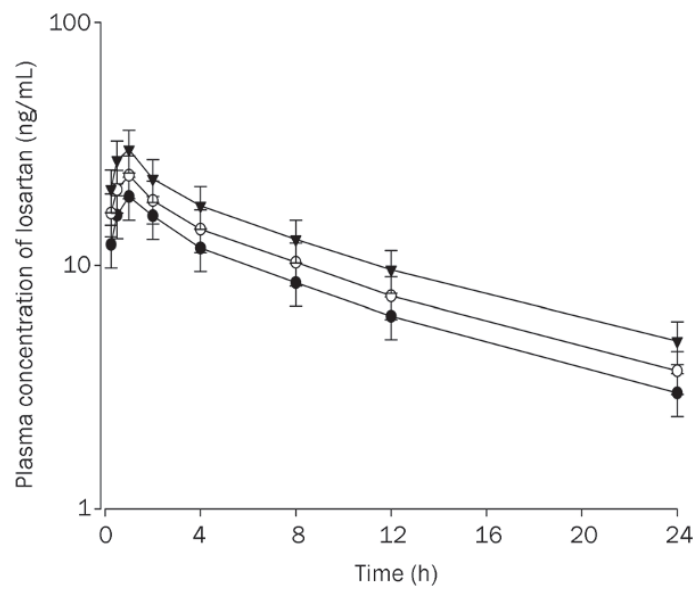

Figure 3. Mean plasma concentration-time profiles of losartan after oral $(9 \mathrm{mg} / \mathrm{kg}$ ) administration of losartan to rats without (control) and with ticlopidine at doses of 4 and $10 \mathrm{mg} / \mathrm{kg}$. Mean $\pm \mathrm{SD}(n=6)$. - $\bullet-$ : Control (only losartan $9 \mathrm{mg} / \mathrm{kg}$ alone); - o-: Losartan $9 \mathrm{mg} / \mathrm{kg}+$ ticlodipine 4 $\mathrm{mg} / \mathrm{kg}$; - $\boldsymbol{\nabla}$-: Losartan $9 \mathrm{mg} / \mathrm{kg}+$ ticlodipine $10 \mathrm{mg} / \mathrm{kg}$. 
Table 1. Pharmacokinetic parameters of losartan after oral (9 mg/kg) administration without (control) and with ticlopidine at doses of 4 and 10 $\mathrm{mg} / \mathrm{kg} . n=6$. ${ }^{\mathrm{b}} \mathrm{P}<0.05$ vs control group (only losartan alone).

\begin{tabular}{lccc}
\hline \multirow{2}{*}{ Parameter } & Control & \multicolumn{2}{c}{ Losartan+Ticlodipine } \\
& & $4 \mathrm{mg} / \mathrm{kg}$ & $10 \mathrm{mg} / \mathrm{kg}$ \\
\hline $\mathrm{AUC}_{0-\infty}\left(\mathrm{ng} \cdot \mathrm{mL}^{-1} \cdot \mathrm{h}\right)$ & $143.1 \pm 33.2$ & $178.9 \pm 34.9$ & $236.0 \pm 39.6^{\mathrm{b}}$ \\
$C_{\max }(\mathrm{ng} / \mathrm{mL})$ & $15.6 \pm 2.2$ & $17.6 \pm 3.0$ & $23.3 \pm 3.7^{\mathrm{b}}$ \\
$t_{\max }(\mathrm{h})$ & $1.00 \pm 0.55$ & $1.00 \pm 0.55$ & $0.84 \pm 0.26$ \\
$t_{1 / 2}(\mathrm{~h})$ & $9.40 \pm 1.51$ & $9.60 \pm 1.54$ & $9.61 \pm 1.64$ \\
$F(\%)$ & $15.6 \pm 3.6$ & $19.5 \pm 4.7$ & $25.7 \pm 5.2^{\mathrm{b}}$ \\
$\mathrm{RB}(\%)$ & 100 & 125 & 165 \\
\hline
\end{tabular}

$\mathrm{AUC}_{0-\infty}$, total area under the plasma concentration-time curve from time zero to infinity; $C_{\max }$, peak plasma concentration; $t_{\max }$, time to reach the peak plasma concentration; $t_{1 / 2}$, terminal half-life; $F$, extent of absolute oral bioavailability; RB, relative bioavailability.

$C_{\max }$ of losartan after oral administration with losartan and 10 $\mathrm{mg} / \mathrm{kg}$ ticlopidine were significantly greater (by $65.0 \%$ and $49.4 \%$, respectively) than those of control rats. The $F$ of losar$\tan$ was $64.7 \%$.

\section{Effect of ticlopidine on the pharmacokinetics of active metabolite EXP-3174}

Rats were given oral administration of losartan $(9 \mathrm{mg} / \mathrm{kg})$ with and without oral ticlopidine at doses of 4 and $10 \mathrm{mg} / \mathrm{kg}$. The mean arterial plasma concentration-time profiles of EXP3174 are shown in Figure 4. The relevant pharmacokinetic parameters of losartan are listed in Table 2. The AUC and $C_{\max }$ of EXP-3174 after oral administration of losartan with $10 \mathrm{mg} / \mathrm{kg}$ ticlopidine were significantly greater than those of control rats (by $41.8 \%$ and $36.8 \%$, respectively). The AUC ratio $\left(\mathrm{AUC}_{\mathrm{EXP}-3174} / \mathrm{AUC}_{\text {losartan }}\right)$ was not significantly decreased $(P>0.05)$ compared to control rats.

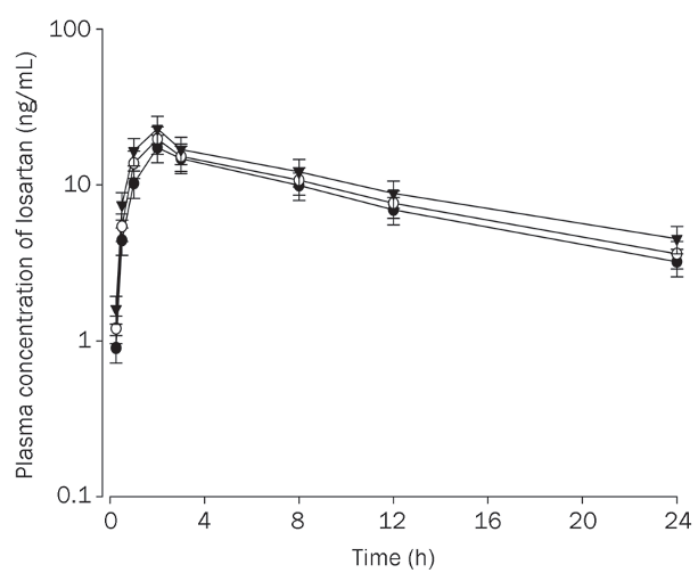

Figure 4. Mean plasma concentration-time profiles of EXP-3174 after oral $(9 \mathrm{mg} / \mathrm{kg}$ ) administration of losartan to rats without and with ticlopidine at doses of 4 and $10 \mathrm{mg} / \mathrm{kg}$. Mean $\pm \mathrm{SD}(n=6)$. $-\bullet^{-}$-: Control (only losartan $9 \mathrm{mg} / \mathrm{kg}$ alone); - --: Losartan $9 \mathrm{mg} / \mathrm{kg}+$ ticlodipine $4 \mathrm{mg} / \mathrm{kg}$; - $\boldsymbol{\nabla}$-: Losartan $9 \mathrm{mg} / \mathrm{kg}+$ ticlodipine $10 \mathrm{mg} / \mathrm{kg}$.
Table 2. Pharmacokinetic parameters of EXP-3174 after oral $(9 \mathrm{mg} / \mathrm{kg})$ administration without (control) and with ticlopidine at doses of 4 and 10 $\mathrm{mg} / \mathrm{kg}$. $n=6 .{ }^{\mathrm{b}} \mathrm{P}<0.05 \mathrm{vs}$ control group (only losartan alone).

\begin{tabular}{lrrr}
\hline \multirow{2}{*}{ Parameter } & Control & \multicolumn{2}{c}{ Losartan+ticlodipine } \\
& & $4 \mathrm{mg} / \mathrm{kg}$ & $10 \mathrm{mg} / \mathrm{kg}$ \\
\hline $\mathrm{AUC}_{0-\infty}\left(\mathrm{ng} \cdot \mathrm{mL}^{-1} \cdot \mathrm{h}\right)$ & $206.1 \pm 33.1$ & $211.0 \pm 41.5$ & $292.3 \pm 44.8^{\mathrm{b}}$ \\
$C_{\max }(\mathrm{ng} / \mathrm{mL})$ & $17.4 \pm 2.40$ & $19.8 \pm 3.18$ & $23.8 \pm 4.72$ \\
$t_{\max }(\mathrm{h})$ & $2.00 \pm 0.63$ & $2.00 \pm 0.63$ & $1.68 \pm 0.52$ \\
$t_{1 / 2}(\mathrm{~h})$ & $7.21 \pm 1.07$ & $7.66 \pm 1.82$ & $8.33 \pm 2.08$ \\
$\mathrm{AUC}$ & $1.44 \pm 0.23$ & $1.19 \pm 0.19$ & $1.23 \pm 0.29$ \\
\hline
\end{tabular}

$\mathrm{AUC}_{0-\infty}$, total area under the plasma concentration-time curve from time zero to infinity; $C_{\max }$, peak plasma concentration; $t_{\max }$, time to reach the peak plasma concentration; $t_{1 / 2}$, terminal half-life.

\section{Effect of ticlopidine on the pharmacokinetics of intravenous losartan}

Mean arterial plasma concentration-time profiles of losartan following intravenous administration of losartan $(3 \mathrm{mg} / \mathrm{kg})$ to rats in the presence or absence of ticlopidine ( 4 and $10 \mathrm{mg} / \mathrm{kg}$ ) are shown in Figure 5. The corresponding pharmacokinetic parameters are shown in Table 3.

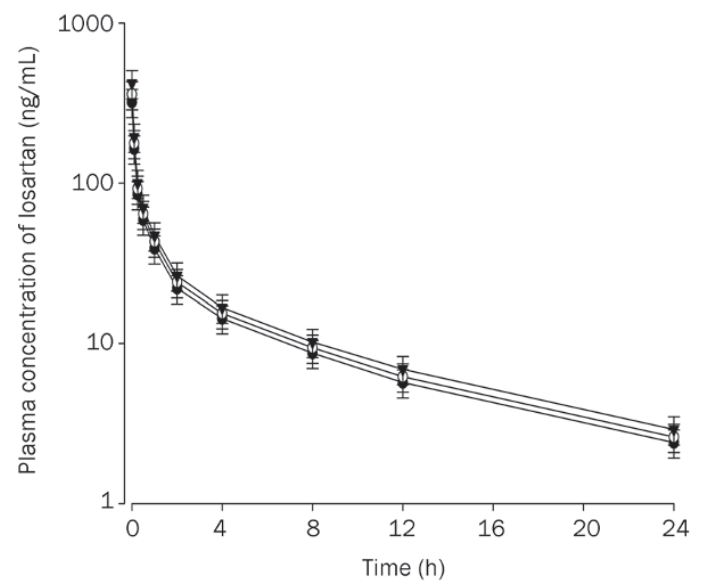

Figure 5. Mean plasma concentration-time profiles of losartan after iv (3 $\mathrm{mg} / \mathrm{kg}$ ) administration to rats without and with ticlopidine at doses of 4 and $10 \mathrm{mg} / \mathrm{kg}$. Mean $\pm \mathrm{SD}(n=6)$. - - -: Control (only losartan $3 \mathrm{mg} / \mathrm{kg}$ alone); - -: Losartan $9 \mathrm{mg} / \mathrm{kg}+$ ticlodipine $4 \mathrm{mg} / \mathrm{kg}$; - $\mathbf{\nabla}$-: Losartan 9 $\mathrm{mg} / \mathrm{kg}+$ ticlodipine $10 \mathrm{mg} / \mathrm{kg}$.

The AUC of losartan was increased by ticlopidine treatment, but was not statistically significant compared to the control. The $t_{1 / 2}$ of losartan was also prolonged, but this increase was not significant. The pharmacokinetics of intravenous losartan was not affected by the concurrent use of ticlopidine, in contrast to those of oral losartan. Accordingly, there was enhanced oral bioavailability in the presence of ticlopidine, while there was no significant change in the pharmacokinetics of intravenous losartan. This finding may be due to the inhibi- 
Table 3. Pharmacokinetic parameters of losartan after intavenous (3 $\mathrm{mg} / \mathrm{kg}$ ) administration to rats without (control) and with ticlopidine at doses of 4 and $10 \mathrm{mg} / \mathrm{kg}$. $n=6$.

\begin{tabular}{lccc}
\hline \multirow{2}{*}{ Parameter } & Control & \multicolumn{2}{c}{ Losartan+ticlodipine } \\
& & $4 \mathrm{mg} / \mathrm{kg}$ & $10 \mathrm{mg} / \mathrm{kg}$ \\
\hline $\mathrm{AUC}_{0-\infty}\left(\mathrm{ng} \cdot \mathrm{mL}^{-1} \cdot \mathrm{h}\right)$ & $288.1 \pm 74.2$ & $314.2 \pm 81.2$ & $345.0 \pm 85.1$ \\
$\mathrm{CLt}\left(\mathrm{mL} \cdot \mathrm{h}^{-1} \cdot \mathrm{kg}^{-1}\right)$ & $3.78 \pm 1.07$ & $3.56 \pm 1.02$ & $3.33 \pm 1.01$ \\
$t_{1 / 2}(\mathrm{~h})$ & $8.7 \pm 2.0$ & $8.8 \pm 2.0$ & $8.9 \pm 2.2$ \\
$\mathrm{RB}(\%)$ & 100 & 108 & 119 \\
\hline
\end{tabular}

$\mathrm{AUC}_{0-\infty}$, total area under the plasma concentration-time curve from time zero to infinity; $C L t$, total body clearance; $t_{1 / 2}$, terminal half-life; RB, relative bioavailability.

tion of CYP3A-mediated metabolism of losartan in the small intestine and/or in the liver rather than the reduction of renal elimination of losartan by ticlopidine.

\section{Discussion}

This study evaluated the effect of ticlopidine on the bioavailability and pharmacokinetics of losartan in rats to investigate a potential drug interaction between the two drugs. In previous pharmacokinetic studies, losartan was administered to rats orally at doses of 3-10 mg/ $\mathrm{kg}^{[15-17]}$. Thus, a $9 \mathrm{mg} / \mathrm{kg}$ dose of losartan was used in the present study.

It has been reported that the pharmacokinetics of losartan are similar between rats and humans ${ }^{[18]}$. In both rats and humans, EXP-3174 has been found in plasma. The F of losartan was reported to be $31.5 \%-38.2 \%$ in rats and $33 \%$ in humans. The urinary excretion of losartan within $24 \mathrm{~h}$ after oral administration was shown to be approximately $0.3 \%$ and $5 \%$ of the dose in rats and humans, respectively, which suggests a small contribution of renal clearance to total body clearance ${ }^{[18]}$. These data support that the rat is a suitable animal model for pharmacokinetic studies of losartan.

Oral administration of losartan with $10 \mathrm{mg} / \mathrm{kg}$ ticlopidine significantly increased the AUC (by 65.0\%), suggesting that ticlopidine can effectively inhibit the metabolism of losartan in the intestine and/or liver. However, the $\mathrm{AUC}_{\mathrm{EXP}-3174}$ was also significantly increased (by $41.8 \%$ ) in the presence of $10 \mathrm{mg} / \mathrm{kg}$ ticlopidine. EXP-3174 is eliminated by both renal (accounting for $55 \%$ of its clearance) and non-renal routes ${ }^{[19]}$. One explanation could be that the renal elimination and/or further metabolism of EXP-3174 might be affected by ticlopidine, although further metabolism of EXP-3174 has not been reported. More experiments will be necessary to prove these hypotheses. Although the $\mathrm{AUC}_{\mathrm{EXP}-3174}$ was also significantly increased in the presence of $10 \mathrm{mg} / \mathrm{kg}$ ticlopidine, the AUC ratio (AUC $\mathrm{EXXP}_{3174}$ / $\left.\mathrm{AUC}_{\text {losartan }}\right)$ was not significantly decreased $(P>0.05)$ compared to control rats. After oral losartan administration, EXP-3174 showed a greater AUC than losartan because of its low clearance rate. Similar results have been reported previously, showing that EXP-3174 has a greater AUC and a longer terminal half-life than losartan in both rats and humans ${ }^{[20,21]}$.
Because losartan is a substrate of P-gp, the effect of ticlopidine on P-gp activity levels of losartan was evaluated using rhodamine-123 in a cell-based assay. The relative cellular uptake of rhodamine-123 was not affected (Figure 2), suggesting that ticlopidine does not inhibit P-gp activity. The inhibitory effects of ticlopidine against CYP2C9- and 3A4-mediated metabolism were confirmed by the employment of recombinant CYP enzymes. As shown in Figure 1, ticlopidine exhibited inhibitory effects against CYP2C9- and 3A4-mediated metabolism with $\mathrm{IC}_{50}$ values of 26.0 and $32.3 \mu \mathrm{mol} / \mathrm{L}$, respectively. This finding shows that the AUC of losartan increased significantly after its oral administration with $10 \mathrm{mg} / \mathrm{kg}$ ticlopidine, although the in vitro CYP inhibition of losartan was not potent. Although in vitro studies are useful methods to study inhibitory mechanisms, they are limited because test conditions may not accurately correspond to in vivo conditions. Thus, there may be some discrepancies between in vivo and in vitro data. In a study using human liver microsomes and recombinant human CYP enzymes, it was reported that ticlopidine is a potent, competitive inhibitor of both CYP2C19 and 2D6, but is only a weak inhibitor of CYP2C9 and $3 \mathrm{~A}^{[22]}$. It was also reported that ticlopidine has a high inhibitory potency for CYP2C19 in vitro and in vivo ${ }^{[23]}$.

CYP1A and 3A isoforms were primarily expressed in rat intestine, whereas CYP2C was not detectable in rat intestine using RT-PCR and immunoblot analysis ${ }^{[24]}$. Thus, the significant increase in AUC of losartan after oral administration with losartan and ticlopidine $(10 \mathrm{mg} / \mathrm{kg})$ may be attributable to the inhibition of CYP2C and 3A subfamilies-mediated losartan metabolism in the liver and/or the intestine rather than the inhibition of P-gp activity by ticlopidine. Similar results were reported showing that concomitant intake of grapefruit juice significantly altered some of the pharmacokinetic parameters of losartan and its metabolite EXP-3174 in healthy volunteers via the inhibition of CYP3A4 metabolism ${ }^{[25]}$. It was also reported that neurological symptoms occurred in an epileptic patient in association with increased carbamazepine levels, due to a probable drug interaction between ticlopidine and carbamazepine (which is mainly metabolized via CYP3A4 $4^{[26]}$ ).

There are likely to be some differences in the enzyme activities of the CYP2C and 3A subfamilies between rats and humans ${ }^{[27]}$. The protein homologies between CYP2C and 3A in rats and humans have been reported to be very similar, $73 \%$ and $77 \%$, respectively ${ }^{[28]}$. For example, the $\mathrm{AUC}_{\text {losartan }}$ and $\mathrm{AUC}_{\mathrm{EXP}-3174}$ were significantly increased and decreased, respectively, by administration of bucolome, a CYP2C9 inhibitor, in both rats and humans ${ }^{[16]}$. This result supports that rat isoforms with very similar enzymatic properties to CYP2C9 could be involved in the metabolic clearance of losartan in rats, although rats do not have the CYP isoforms orthologous to human CYP2C9.

The significant increase in the AUC of losartan after oral administration with losartan and ticlopidine $(10 \mathrm{mg} / \mathrm{kg})$ may be attributable to the inhibition of CYP2C and 3A subfamiliesmediated losartan metabolism in the small intestine and/or in the liver. The inhibition of P-gp in the small intestine and the 
reduction of renal elimination of losartan by ticlopidine are unlikely to be causal factors.

\section{Author contribution}

Si-hyung YANG and Young-ah $\mathrm{CHO}$ designed the research; Young-ah CHO performed the research; Si-hyung YANG analyzed the data; Jun-shik CHOI wrote the paper.

\section{References}

1 Triggle DJ. Angiotensin II receptor antagonism: losartan - sites and mechanisms of action. Clin Ther 1995; 17: 1005-30.

2 Yasar U, Tybring G, Hidestrand M, Oscarson M, Ingelman-Sundberg M, Dahl ML, et al. Role of CYP2C9 polymorphism in losartan oxidation. Drug Metab Dispos 2001; 29: 1051-6.

3 Wong PC, Price WA Jr, Chiu AT, Duncia JV, Carini DJ, Wexler RR, et al. Nonpeptide angiotensin II receptor antagonists. XI. Pharmacology of EXP3174: an active metabolite of DuP 753, an orally active antihypertensive agent. J Pharmacol Exp Ther 1990; 255: 211-7.

4 Soldner A, Spahn-Langguth H, Mutschler E. HPLC assays to simultaneously determine the angiotensin-AT1 antagonist losartan as well as its main and active metabolite EXP-3174 in biological material of humans and rats. J Pharm Biomed Anal 1998; 16: 863-73.

5 Saltiel E, Ward A. Ticlopidine. A review of its pharmacodynamic and pharmacokinetic properties, and therapeutics efficacy in plateletdependent disease states. Drugs 1987; 34: 222-62.

6 Ito MK, Smith AR, Lee ML. Ticlopidine: a new platelet aggregation inhibitors. Clin Pharm 1992; 11: 603-17.

7 Flores-Runk P, Raasch RH. Ticlopidine and antiplatelet therapy. Ann Pharmacother 1993; 27: 1090-8.

8 Birmelé B, Lebranchu Y, Bagros P, Nivet H, Furet $\mathrm{Y}$, Pengloan J. Interaction of cyclosporin and ticlopidine. Nephrol Dial Transplant 1991; 6: 150-1.

9 Knudsen JB, Bastain W, Sefton CM, Allen JG, Dickinson JP. Pharmacokinetics of ticlopidine during chronic oral administration to healthy volunteers and its effects on antipyrine pharmacokinetics. Xenobiotica 1992; 22: 579-89.

10 Choi DH, Li C, Choi JS. Effects of myricetin, an antioxidant, on the pharmacokinetics of losartan and its active metabolite, EXP-3174, in rats: possible role of cytochrome P450 3A4, cytochrome P450 2C9 and P-glycoprotein inhibition by myricetin. J Pharm Pharmacol 2010; 62: 908-14.

11 Zarghi A, Foroutan SM, Shafaati A, Khoddam A. A rapid HPLC method for the determination of losartan in human plasma using a monolithic column. Arzneimittelforschung 2005; 55: 569-72.

12 Crespi CL, Miller VP, Penman BW. Microtiter plate assays for inhibition of human, drug-metabolizing cytochromes P450. Anal Biochem 1997; 248: 188-90.

13 Gibaldi M, Perrier D. Pharmacokinetics. 2nd ed. New York: MarcelDekker; 1982
14 Chiou WL. Critical evaluation of potential error in pharmacokinetic studies using the linear trapezoidal rule method for the calculation of the area under the plasma level-time curve. J Pharmacokinet Biopharm 1978; 6: 539-46.

15 Shibasaki M, Fujimori A, Takanashi M, Kusayama T, Tokioka T, Satoh Y, et al. Pharmacological profile of YM358, a novel nonpeptide angiotensin AT1 receptor antagonist. Eur J Pharmacol 1997; 335: 167-73.

16 Kobayashi M, Takagi M, Fukumoto K, Kato R, Tanaka K, Ueno K. The effect of bucolome, a CYP2C9 inhibitor, on the pharmacokinetics of losartan. Drug Metab Pharmacokinet 2008; 23: 115-9.

17 Yan YD, Kim HK, Seo KH, Lee WS, Lee GS, Woo JS, et al. The physicochemical properties, in vitro metabolism and pharmacokinetics of a novel ester prodrug of EXP3174. Mol Pharm 2010; 7: 2132-40.

18 Yoshitani T, Yagi H, Inotsume N, Yasuhara M. Effect of experimental renal failure on the pharmacokinetics of losartan in rats. Biol Pharm Bull 2002; 25: 1077-83.

19 Tamaki T, Nishiyama A, Kimura S, Aki Y, Yoshizumi M, Houchi H, et al. EXP3174: the major active metabolite of losartan. Cardiovasc Drug Rev 1997; 15: 122-36.

20 Munafo A, Christen Y, Nussberger J, Shum LY, Borland RM, Lee RJ, et al. Drug concentration response relationships in normal volunteers after oral administration of losartan, an angiotensin 11 receptor antagonist. Clin Pharmacol Ther 1992; 51: 513-21.

21 Lo MW, Goldberg MR, McCrea JB, Lu H, Furtek Cl, Bjornsson TD. Pharmacokinetics of losartan, an angiotensin II receptor antagonist, and its active metabolite EXP-3174 in humans. Clin Pharmacol Ther 1995; 58: 641-9

22 Ko JW, Desta Z, Soukhova NV, Tracy T, Flockhart DA. In vitro inhibition of the cytochrome P450 (CYP450) system by the antiplatelet drug ticlopidine: potent effect on CYP2C19 and CYP2D6. Br J Clin Pharmacol 2000; 49: 343-51.

23 Foti RS, Wahlstrom JL. CYP2C19 inhibition: the impact of substrate probe selection on in vitro inhibition profiles. Drug Metab Dispos 2008; 36: 523-8.

24 Kaminsky LS, Zhang QY. The small intestine as a xenobiotic-metabolizing organ. Drug Metab Dispos 2003; 31: 1520-5.

25 Zaidenstein R, Soback S, Gips M, Avni B, Dishi V, Weissgarten Y, et al. Effect of grapefruit juice on the pharmacokinetics of losartan and its active metabolite E3174 in healthy volunteers. Ther Drug Monit 2001; 23: 369-73

26 Brown RI, Cooper TG. Ticlopidine-carbamazepine interaction in a coronary stent patient. Can J Cardiol 1997; 13: 853-4.

27 Cao X, Gibbs ST, Fang L, Miller HA, Landowski CP, Shin HC. Why is it challenging to predict intestinal drug absorption and oral bioavailability in human using rat model. Pharm Res 2006; 23: 167586.

28 Lewis DFV. Cytochrome P450. Substrate specificity and metabolism. In: Cytochromes P450: structure, function, and mechanism. Bristol: Taylor \& Francis; 1996; p 122-3. 